\title{
O PEWNYCH PODOBIEŃSTWACH I ZASADNICZEJ RÓŻNICY W INTERPRETOWANIU TEKSTÓW PRAWNYCH ORAZ LITERACKICH
}

\begin{abstract}
Streszczenie. Celem artykułu jest ukazanie, że na pewnym poziomie interpretacyjnym zarówno teksty prawne, jak i teksty literackie mają charakter niesamoistny - dla potrzeb tego rodzaju zbliżenia perspektywy analizy tekstów prawnych i literackich wykorzystuję odpowiednio elementy teorii derywacyjnej dla tekstów prawnych oraz elementy teorii Susan Sontag oraz Erica Donalda Hirscha dla tekstów literackich. Przypisanie cechy niesamoistności znaczenia tekstom prawnym oraz literackim wymusza przyjrzenie się możliwym „pozatekstowym źródłom”, pozwalającym na zrekonstruowanie znaczenia tych dwóch rodzajów tekstów. Nie może umknąć jednak uwadze zasadnicza rozbieżność warunkująca możliwości w interpretowaniu tekstów prawnych oraz literackich - interpretacja tekstów prawnych ma na celu ujednolicanie ich znaczeń, a interpretacja tekstów literackich (zwłaszcza w duchu ,anarchizmu interpretacyjnego”) może mieć na celu mnożenie wyinterpretowanych znaczeń.
\end{abstract}

Słowa kluczowe: niesamoistność tekstu, teoria derywacyjna, poziomy lokalizacji znaczenia tekstu, ujednolicanie znaczenia tekstu.

\section{ON CERTAIN SIMILARITIES AND A FUNDAMENTAL DIFFERENCE IN THE INTERPRETATION OF LEGAL AND LITERARY TEXTS}

\begin{abstract}
The aim of the article is to show that at a certain level of interpretation, both legal texts and literary texts are non-intrinsic - for the purposes of this kind of approximation of the perspective of the analysis of legal and literary texts, I use respectively elements of derivative theory for legal texts and elements of the theory of Susan Sontag and Eric Donald Hirsch for literary texts. Ascribing the feature of non-intrinsicality to legal and literary texts forces one to look at possible "extra-textual sources" allowing for the reconstruction of the meaning of these two types of texts. However, the fundamental difference that determines the possibilities of interpreting legal and literary texts must not be overlooked - the interpretation of legal texts is aimed at unifying their meanings, and the interpretation of literary texts (especially in the spirit of "interpretive anarchism") may be aimed at multiplying the interpreted meanings.
\end{abstract}

Keywords: non-intrinsicality of texts, derivative theory, levels of location of meaning, unifying of meaning of texts.

* Uniwersytet Łódzki, Wydział Prawa i Administracji, Katedra Teorii i Filozofii Prawa, jedrzej.janicki@edu.uni.lodz.pl 


\section{WPROWADZENIE}

Nawet najbardziej podstawowe intuicje wskazują, że interpretacja tekstu prawnego musi być odmienna od interpretacji tekstu literackiego. Jak się wydaje, intuicji tej odpowiada stwierdzenie Gustava Radbrucha, który zauważa, że w „miarę wyłaniania się poszczególnych obszarów kultury prawo i sztuka oddalały się jednak od siebie, by na ostatek popaść we wzajemną wrogość" (Radbruch 2009, 116-117). W artykule tym postaram się wskazać jednak, że tak jednowymiarowe podejście, które prezentuje cytowana wypowiedź Radbrucha w kontekście analizy tekstu prawnego i tekstu literackiego jest nieuprawnione. W artykule tym skupię się w pierwszej jego części na podobieństwach między tymi dwoma rodzajami tekstów: 1) cesze niesamoistności tekstu, którą na pewnym poziomie interpretacyjnym przypisać można zarówno tekstom prawnym, jak i literackim; 2) granicach swobody interpretacyjnej (choć są one zgoła różnie ukształtowane dla interpretacji tekstów prawnych i literackich, to jednak dla obu tych rodzajów tekstów pewne granice można wskazać). Zasadniczą różnicą pomiędzy interpretacją tych dwóch rodzajów tekstu, którą opisuję w dalszej części artykułu, jest ogólny cel, jaki przyświeca interpretacji tekstów prawnych oraz literackich - w pierwszym przypadku jest to „zacieranie” różnic w możliwych znaczeniach danego tekstu, a w drugim „mnożenie” tych różnic.

\section{NIESAMOISTNOŚĆ TEKSTÓW PRAWNYCH I TEKSTÓW LITERACKICH}

To, co uznaję za podobieństwo tekstów prawnych i literackich, wydać się może na pierwszy rzut oka ich różnicą - teksty prawne mają charakter niesamoistny, natomiast teksty literackie mają charakter samoistny. Pewną wskazówkę, w jaki sposób rozumieć należy samoistność i niesamoistność, daje Roman Ingarden - samoistność ujmuje on następująco: „coś istnieje samoistnie [...] jeżeli ma samo w sobie swój fundament bytowy. Ma zaś w sobie taki fundament, jeżeli samo w sobie jest immanentnie określone" (Ingarden 1960, 92). A contrario więc Ingarden stwierdza, że „Coś istnieje niesamoistnie [...], jeżeli swój fundament bytowy ma nie w sobie samym, lecz w czymś innym” (Ingarden 1960, 94). Na potrzeby niniejszego artykułu jako samoistność tekstu rozumiem możliwość zrekonstruowania jego znaczenia (zinterpretowania go) wyłącznie na podstawie samego tego tekstu, natomiast niesamoistność tekstu oznacza konieczność odwołania się również do kryteriów pozatekstowych w celu interpretacji tego tekstu. Tak naprawdę chodzi więc o samoistność i niesamoistność znaczenia tekstu. Przypisanie tekstom prawnym cechy niesamoistności oraz tekstom literackim samoistności wymaga jednak pewnego uzasadnienia. 
Tekst prawny nazwać można niesamoistnym przy przyjęciu kluczowego założenia koncepcji derywacyjnej ${ }^{1}$ - mianowicie przy założeniu rozróżnienia przepisu prawnego od normy prawnej ${ }^{2}$. Tekst prawny ma więc charakter dwupoziomowy - na gruncie koncepcji derywacyjnej mówić można o poziomie przepisów prawnych i poziomie norm prawnych. Jak wskazuje Agnieszka Choduń, oba te poziomy

różnią się między sobą nie tylko tym, że są to wypowiedzi o różnym statusie semiotycznym, ale przede wszystkim tym, że wypowiedzi deskryptywne odczytane na poziomie deskryptywnym (poziom przepisów - J. J.) oraz wypowiedzi deskryptywne odczytane na poziomie normatywnym (poziom norm - J. J.) mają różną treść (Choduń 2016, 58).

Jeden przepis prawny zawierać może w sobie wszystkie elementy normy prawnej, niektóre jej elementy (tzw. rozczłonkowanie syntaktyczne) oraz elementy więcej niż jednej normy prawnej (tzw. kondensacja norm w przepisach). Stwierdzić więc można, że ,akty normatywne i przepisy prawne nie są prawem; prawo jest odtwarzane z przepisów w procesie wykładni" (Czepita, Wronkowska, Zieliński 2013, 10). Przepisy prawne są więc jedynie „półfabrykatami prawa”. Jak słusznie zauważają Paweł Jabłoński i Przemysław Kaczmarek,

sposób dalszego opracowywania tego pólfabrykatu, a więc ustalanie jakie dokładnie przepisy i w jakim brzmieniu trzeba wziąć pod uwagę [faza porządkująca], jakie wyrażenie normokształtne należy z nich odtworzyć [faza rekonstrukcyjna] i wreszcie jakie normy wyklarować z tych ostatnich [faza percepcyjna] - wszystko to rozgrywa się poza (pogrubienie - J. J.) tekstem prawnym, choć w ścisłym z nim związku (Jabłoński, Kaczmarek 2020, 55).

Niesamoistność tekstu prawnego (szczególnie wyraźnie widoczna na gruncie teorii derywacyjnej) polega więc na tym, że dla jego odczytania (poznania) konieczna jest jego interpretacja - polegająca w tym wypadku na przejściu z „,poziomu przepisów” na „poziom norm”. Zachodzi konieczność „intelektualnego obrobienia" tekstu prawnego - bez tego aspektu pozostaje on bezużyteczny na etapie stosowania prawa. Chodzi więc o poznanie zawartości normatywnej tego tekstu, a nie wyłącznie jego percypowanie ${ }^{3}$. Choć nie będzie to stanowiło punktu dal-

${ }^{1}$ Choć, jak wskazuje Maciej Zieliński, ,pierwszym z tych fundamentalnych elementów derywacyjnych nie jest, jak się powszechnie sądzi, rozróżnienie pojęciowe między norma prawna a przepisem prawnym, lecz metodologiczne założenie dotyczące kryterium źródeł ukształtowania adekwatnej koncepcji wykładni” (Zieliński 2006, 95). Owo założenie metodologiczne przyjmowane na gruncie koncepcji derywacyjnej polega na tym, ,[...] że zasady postępowania interpretacyjnego wyznaczane są nie przez czyjekolwiek zachowania się interpretacyjne (tak jak ma to miejsce w teorii semantycznej intensjonalnej Jerzego Wróblewskiego - J. J.), lecz przez rzeczywiste cechy tekstów prawnych, które odpowiednio rozpoznane narzucają taki, a nie inny sposób postępowania interpretacyjnego" (Zieliński 2006, 95).

${ }^{2}$ Pojęciowe rozróżnienie ,przepisu prawa” od „,normy prawnej” wprowadził w 1960 roku Zygmunt Ziembiński (Ziembiński 1960, 105-122).

${ }^{3}$ Poprzez ,percypowanie” i ,percepcję” tekstu rozumiem jego bezpośredni, niezapośredniczony intelektualnie odbiór tekstu - rozumienia tego nie należy mylić z „fazą percepcyjną”, która stanowi finalny etap procesu wykładni podług modelu teorii derywacyjnej. 
szych rozważań, to w tym miejscu wskazać można, że wspomniana zawartość normatywna jest aspektem, który rozróżnia teksty prawne i teksty literackie - cecha ta immanentnie związana jest z tekstami prawnymi, natomiast, co oczywiste, teksty literackie zawartością normatywną nie muszą się charakteryzować ${ }^{4}$. Odczytanie tekstu prawnego wyłącznie przez pryzmat jego percypowania (czyli jako tekstu samoistnego) wydaje się, że nie niesie w sobie ani żadnej korzyści dla dyskursu prawnego, ani nie wywołuje sądu o charakterze estetycznym ${ }^{5}$.

Zgoła odmienną perspektywę zbudować można dla potrzeb poczynienia uwag dotyczących tekstu literackiego. Jak pisze Wiktor Szkłowski, „,elem obrazu nie jest ułatwienie nam zrozumienia przedmiotu, lecz wywołanie specyficznego sposobu percepcji tego przedmiotu, stworzenie jego widzenia, a nie poznawania" (Szkłowski 2006, 105). Choć Szkłowski w przytoczonym fragmencie pisze o „celu obrazu", to uwag jego nie należy ograniczać do sztuk wizualnych, gdyż według Szkłowskiego tekst literacki wywołuje w świadomości odbiorcy obrazy, co powoduje, że jego uwagi zachowują prawomocność również właśnie w kontekście tekstów literackich (sam zresztą w przytaczanym tekście powołuje jako przykład takiego ujmowania sztuki prozę Lwa Tołstoja). W najogólniejszym więc rysie myśl Szkłowskiego opiera się na uwypukleniu i podkreśleniu doniosłości samego aktu percypowania sztuki, a nie jej rozumienia czy poznawania. Bardzo podobnym tropem podąża Susan Sontag, gdy w charakterystyczny dla siebie sposób stwierdza, że „nie potrzebujemy hermeneutyki sztuki, ale erotyki sztuki” (Sontag 2012b, 26). Hermeneutyka $\mathrm{w}$ tym kontekście utożsamiana może być z interpretacją, a erotyka $\mathrm{z}$ bezpośrednim odbiorem sztuki. Jeszcze inaczej mówiąc, hermeneutyka to poznanie dzieła, a erotyka to jego percypowanie. Sam proces interpretacji dzieła podyktowany jest koniecznością podkreślania treści dzieła sztuki, co powoduje, że dzieło sztuki po procesie interpretacji w odbiorze utożsamiane jest właśnie z treścią - wszak interpretuje się wyłącznie treść, a nie formę ${ }^{6}$. Konieczność dowartościowania bezpośredniego percypowania dzieła sztuki (także literackiego), a nie jego poznawania, wskazywałaby na to, że tekst literacki ma charakter samoistny, co w tym wypadku oznacza, że w procesie jego odbioru nie ma potrzeby odwoływania się do jakichkolwiek elementów pochodzących spoza samego tekstu.

Tak zarysowany model postrzegania dzieł literackich (dzieł sztuki) stoi w sprzeczności z przytoczonymi ustaleniami dotyczącymi tekstu prawnego. Moim

\footnotetext{
${ }^{4}$ Choć należy również pamiętać, że wskazać można w historii literatury teksty literackie, które mogły nieść w sobie jakiś rodzaj implicite zawartej doniosłości normatywnej - przykładem chociażby powieść Dżuma Alberta Camus, którą odczytywać można jako dyrektywę wskazującą wzór powinnego zachowania w sytuacji ogólnego zagrożenia danej społeczności.

${ }^{5}$ Choć Anne Teissier-Ensminger w książce La fortune esthétique du Code civil des Français (2004) traktuje Kodeks Napoleona jako artefakt estetyczny, któremu przysługuje atrybut piękna i który rozpatrywany może być jako bodziec wywołujący sąd estetyczny.

${ }^{6}$ Co stoi w sprzeczności z postulowanym przez Sontag ujęciem kategorii stylu, podług którego to ujęcia styl jest nierozdzielalnym złożeniem formy i treści (zob. Sontag 2012a, 27-56).
} 
zdaniem, te dwie zgoła odmienne perspektywy nie stanowią barier nieprzekraczalnych. By jednak wskazać na możliwą płaszczyznę porozumienia między interpretacją tekstu prawnego a tekstu literackiego podkreślić trzeba, że nawet krytycznie nastawiona do interpretacji (rozumienia) Sontag wskazuje, że ,interpretacja traktuje zmysłowe doświadczenie dzieła jako coś oczywistego, punkt wyjścia do dalszych działań. Dziś oczywistość ta zanika" (Sontag 2012b, 25). Z przytoczonego fragmentu wynika, że Sontag występuje przeciw „zanikającej obecnie konieczności zmysłowego doświadczania dzieła", a nie przeciw interpretacji w ogólności. Myśl Sontag odczytywać więc trzeba raczej jako postulat dowartościowania bezpośredniego odbioru, a nie jako swoisty zakaz interpretacji. Przyjąć więc można, że już po etapie percypowania dzieła nastąpić może jego dalsza analiza. Tak jak na poziomie samego percypowania dzieła literackiego stwierdzić można, że tekst tego dzieła jest samoistny, tak przy jego późniejszej interpretacji staje się niesamoistny - a tym samym zbliża się do tekstu prawnego. Powyższe uwagi wskazywałyby na możliwość ujęcia tekstu literackiego jako tekstu o charakterze samoistnym. Ta perspektywa nie odnosi się jednak do interpretacji tekstu, a wyłącznie jego stricte „estetycznego” percypowania. W gruncie rzeczy na poziomie percypowania tekstu literackiego samo rozpatrywanie go jako niesamoistnego jest bezzasadne - wszak ewentualna niesamoistność istotna jest dopiero na poziomie znaczenia tekstu. Znaczenie tekstu za to dla samego percypowania dzieła pozostaje nieistotne.

Prawomocne przejście z poziomu Sontagowskiego percypowania dzieła sztuki na poziom jego rozumienia zapewnia model interpretacji obiektywnej autorstwa Erica Donalda Hirscha. Koncepcję tego amerykańskiego teoretyka literatury uznać można za model dopełniający rozważania Sontag. Najogólniej rzecz ujmując - można przyjąć, że interpretacja obiektywna (która nakierowana jest na zrozumienie dzieła literackiego) pojawić się może dopiero po odbiorze dzieła poprzez jego zmysłowe doświadczenie. W tym wypadku poznanie chronologicznie poprzedzone musi być doświadczeniem danego obiektu (w tym wypadku dzieła literackiego). Zmysłowe doświadczenie i poznanie nie „znoszą się” wzajemnie, o ile nie unieważniamy pierwszego aspektu na rzecz drugiego. Wydaje się, że możliwe jest poprzestanie wyłącznie na zmysłowym doświadczeniu danego dzieła bez przeprowadzania jego interpretacji (poznawania) - przy należytym dowartościowaniu tego zmysłowego doświadczenia nic nie stoi jednak na przeszkodzie, aby interpretację również przeprowadzić (choć wydaje się, że nie jest to konieczne dla „estetycznego” obcowania z dziełem). Przypisując więc tekstowi literackiemu cechę samoistności/niesamoistności należy rozpatrzyć, na którym etapie odbioru dzieła się znajdujemy - jeśli na etapie jego zmysłowego doświadczenia, to tekst jest samoistny, natomiast jeśli na etapie jego poznania, to tekst jest niesamoistny.

Model interpretacji obiektywnej Hirscha zakłada, że poznanie dzieła literackiego składa się z dwóch etapów - „rozumienia” oraz „krytyki”. Hirsch wskazuje na to, że „rozumienie [...] jest zarówno logicznie jak i psychologicznie 
wcześniejsze od tego, co powszechnie nazywamy krytyką" (Hirsch 1977, 289). Warunkiem koniecznym do dokonania krytyki danego dzieła sztuki jest jego zrozumienie - chociażby na najbardziej podstawowym poziomie. To rozróżnienie prowadzi do kluczowej dla myśli Hirscha dychotomii celów związanych z pracą nad tekstem literackim:

1) Meaning - opis immanentnego (niezmiennego) znaczenia utworu.

2) Significance - wartościowanie i ukazywanie kontekstowości dzieła oraz budowanie jego właściwej interpretacji.

Dla Hirscha bardzo ważne jest ścisłe rozgraniczenie tych dwóch celów badawczych, gdyż ewentualne częste nieporozumienia spowodowane są właśnie budowaniem ,otwartych” interpretacji przez odbiorcę tekstu jeszcze na poziomie meaning, czyli na poziomie uchwytywania immanentnego, zamierzonego przez twórcę, znaczenia utworu. Hirsch zakłada istnienie autorskiego znaczenia tekstu, które jest „niezmienne i odtwarzalne” (Hirsch 1977, 296), które to właśnie znaczenie badacz ma uchwycić. Celem badacza na etapie meaning jest więc tak naprawdę uzyskanie obiektywnej wiedzy ( $k$ nowledge) o danym utworze. Na etapie meaning tekst literacki pozostaje jednak nadal samoistny - dla zrekonstruowania owego meaning utworu nie ma wszak potrzeby odwoływania się do jakichkolwiek aspektów znajdujących się ,poza” samym tekstem. Poziom significance jest już za to wartościowaniem dzieła, ukazaniem jego relacyjności i potencjalnej wieloznaczności w zależności od kontekstu, w jakim dzieło to zostanie odczytane. Ten poziom analizy jest jednak uzależniony z jednej strony od wcześniejszych ustaleń co do znaczenia tekstu (z poziomu meaning), a z drugiej od „ukontekstowienia” danego tekstu, czyli osadzenia go w sieci kulturowych powiązań (z poziomu significance). Na poziomie significance tekst literacki nie jest już samoistny, gdyż dla jego interpretacji niezbędne jest odwołanie się do aspektów znajdujących się „poza” samym tekstem.

Podsumowując powyższe rozważania dotyczące samoistności tekstu literackiego stwierdzić można, że aby określić samoistność/niesamoistność tekstu należy w pierwszej kolejności podzielić odbiór dzieła na trzy etapy: 1) etap percypowania (zaczerpnięty z koncepcji Sontag); 2) etap rekonstrukcji meaning (zaczerpnięty z koncepcji Hirscha) oraz 3) etap rekonstrukcji significance (również zaczerpnięty z koncepcji Hirscha). Dla dwóch pierwszych etapów tekst literacki pozostaje samoistny, natomiast dla przeprowadzenia trzeciego wymienionego etapu uznać należy, że tekst literacki jest niesamoistny.

Powyżej poczynione uwagi wskazują na pewne zasadnicze różnice, lecz również na pewne zasadnicze podobieństwa w ujmowaniu tekstu prawnego i tekstu literackiego. Przede wszystkim w przypadku tekstu prawnego jako nieistotną pominąć można fazę percypowania tekstu, która w odbiorze dzieła sztuki na mocy rozważań Sontag odgrywa tak zasadniczą rolę. Pomiędzy derywacyjną teorią dotyczącą tekstu prawnego a interpretacją obiektywną tekstu literackiego zachodzą jednak podobieństwa. Przede wszystkim oba te modele tak naprawdę przyjmują 
dwupoziomowość analizy tekstu. Być może etap meaning rozpatrywać można jako odległy analogon poziomu przepisów prawnych, a etap significance jako odpowiednik poziomu norm prawnych, jednak istotniejsze według mnie jest to, że tekst literacki na etapie significance interpretacji obiektywnej oraz tekst prawny podług teorii derywacyjnej mają charakter niesamoistny. Przypisanie tej cechy obu rodzajom analizowanych tekstów uprawomocnia pytanie o poziom lokalizacji znaczenia tekstu prawnego i tekstu literackiego - skoro teksty są znaczeniowo niesamoistne, to oznacza to, że to znaczenie z jakichś ,źródeł” musi być uzyskiwane.

\section{GRANICE SWOBODY INTERPRETACYJNEJ TEKSTU PRAWNEGO ORAZ TEKSTU LITERACKIEGO}

Na podstawie tego, że tekst prawny ma charakter niesamoistny wywodzić można, iż prawnicy na poziomie stosowania prawa nie są związani wyłącznie tekstem prawnym. Jabłoński i $\operatorname{Kaczmarek}^{7}$ (2017, 15-22), rekonstruując granice władzy prawniczej, wskazują na następujący jej układ: 1) kultura polityczno-prawna; 2) tekst prawny; 3) kultura prawnicza oraz 4) indywidualne wyczucie aksjologiczne. Autorzy, za Markiem Smolakiem (Smolak 2003, 32-33), przez kulturę polityczno-prawną rozumieją ,funkcjonującą w danym społeczeństwie moralność polityczną, dostarczającą podstawowego kośćca aksjologicznego" (Jabłoński, Kaczmarek 2017, 15). Przykładem elementu współtworzącego kulturę polityczno-prawną może być poszanowanie dla godności ludzkiej. Przez tekst prawny autorzy, wzorem Zielińskiego (np. Zieliński 2017), rozumieją zbiór wszystkich przepisów prawnych obowiązujących w danym miejscu i w danym czasie. Kultura prawnicza to według autorów ,wypracowany przez pokolenia jurystów i związany ze społecznym podziałem pracy, zespół wiedzy i umiejętności niezbędnych do poprawnego stosowania prawa" (Jabłoński, Kaczmarek 2017, 15-16). Czwartą grupę stanowią czynniki podmiotowe, które mają charakter indywidualizujący i łączą się ocenami etycznie wartościującymi wydawanymi przez poszczególnych prawników (Jabłoński, Kaczmarek 2017, 16). Na etapie stosowania prawa prawnik związany jest więc również elementami pochodzącymi spoza samego tekstu prawnego. Gdyby tekst prawny był samoistny, to nie byłoby potrzeby poszukiwania elementów „,pozatekstowych” dla jego właściwego zastosowania - jego znaczenie lokalizowane jest więc zarówno w nim samym, jak i poza nim. Z drugiej jednak strony dowolność interpretatora w poszukiwaniu znaczenia tekstu prawnego jest

${ }^{7}$ Autorzy w swoich rozważaniach uwzględniają ujęcie władzy w jej dwóch aspektach - normatywnym oraz realnym. Rozróżnienie to autorzy przyjmują za Krzysztofem Pałeckim (Pałecki 1988, 129). W ujęciu normatywnym o władzy mówić można, gdy możliwe jest wskazanie normy wyposażającej daną grupę osób w kompetencje do podejmowania określonego rodzaju decyzji. W aspekcie realnym za to władza to rzeczywisty zespół działań podejmowanych przez konkretne osoby. 
ograniczona do wspomnianych powyżej czterech aspektów. Nie należy jednak zapominać, że nawet na gruncie przytoczonych uwag Jabłońskiego i Kaczmarka jednym z zasadniczych elementów ograniczających władzę prawniczą jest sam tekst prawny. Pozostając na gruncie derywacyjnej teorii wykładni wskazać można na tzw. granice wykładni prawa, związane z interpretacją samego tekstu prawnego. Choć pojęcie granic wykładni prawa może być rozmaicie rozumiane ${ }^{8}$, to jednak na gruncie derywacyjnej teorii wykładni odwołać się należy do granic wykładni o charakterze zakresowym. Jak piszą Choduń i Zieliński, tak nazwane granice wykładni polegają na tym, że

[...] znaczenia ustalone w oparciu o językowe dyrektywy wykładni stanowią łącznie, na zasadzie sumy logicznej, zbiór tych możliwych znaczeń, z których, przy pomocy dyrektyw interpretacyjnych pozajęzykowych [...] zostanie dokonany wybór tego jednego jedynego znaczenia, które będzie efektem całego procesu wykładni (Choduń, Zieliński 2009, 91).

Dyrektywy językowe wyznaczają więc zakres potencjalnych znaczeń, w ramach którego interpretator, dzięki zastosowaniu dyrektyw pozajęzykowych, wybrać może to jedno, właściwe $\mathrm{w}$ danym przypadku znaczenie.

Pokrótce omówione granice władzy prawniczej rozumieć można jako wskazanie „źródel”, na podstawie których możliwa jest rekonstrukcja znaczenia tekstu prawnego, przeprowadzana na etapie stosowania prawa. Wydaje się, że można również wskazywać „granice władzy interpretatora tekstu literackiego” - tożsame byłoby to ze wskazywaniem ,źródeł”, na podstawie których możliwe jest uzyskiwania znaczenia tego rodzaju tekstu (czyli poziom significance). Anarchizm interpretacyjny (tekstów literackich) ma jednak również swoje granice - jak pisze Andrzej Szahaj, „[...] gra ze znaczeniem ma swoje granice, które można uchwycić, jeśli rozpozna się zestawy kulturowych przedrozumień [przesądzeń] sterujących różnymi interpretacjami” (Szahaj 1997, 26). Nie można więc mówić o jednej poprawnej interpretacji, lecz raczej o całej grupie możliwych interpretacji tekstu, które w zależności od tego, w otoczeniu jakich „kulturowych przedrozumień" się znajdują, uznane mogą zostać za przekonujące bądź nieprzekonujące (a nie za poprawne bądź niepoprawne). Dowolność interpretacyjna tekstu literackiego jest więc o wiele szersza niż tekstu prawnego, jednak również ona nie ma charakteru nieograniczonego - interpretator (w sposób świadomy lub nieświadomy) zdeterminowany jest przez kulturowe uwarunkowania, w których się znajduje.

${ }^{8} \mathrm{Na}$ gruncie sformułowanej przez Wróblewskiego zasady clara non sunt interpretanda mówić można o początkowej granicy wykładni, podczas gdy sformułowana przez Ziembińskiego (zob. Ziembiński 2004, 237) zasada interpretatio cessat in claris (której to formuły, wbrew temu, co pisze sam Ziembiński, nie należy sprowadzać do reguły clara non sunt interpretanda) stanowiłaby o granicach końca wykładni. 


\section{ZASADNICZY CEL PRZYŚWIECAJĄCY INTERPRETACJI TEKSTU PRAWNEGO ORAZ TEKSTU LITERACKIEGO}

W tym miejscu podkreślić trzeba jednak pewną zasadniczą rozbieżność interpretacji tekstu prawnego i interpretacji tekstu literackiego. W pierwszym wypadku czynność interpretacji nakierowana musi być na możliwość wykorzystania zinterpretowanego przepisu jako podstawy rozstrzygnięcia - przy takim rozumieniu interpretacja tekstu prawnego nakierowana jest na osiągniecie określonego celu, którym jest możliwość zastosowania generalno-abstrakcyjnej regulacji w indywidualno-konkretnym przypadku. Najogólniej rzecz ujmując, stwierdzić można, że organy dokonują interpretacji tekstów prawnych by rozstrzygnąć określony spór. Na gruncie polskiej literatury przedmiotu przyjąć można, że generalnie celem wykładni prawa jest ,ustalenie rzeczywistego znaczenia norm prawnych zawartych w przepisach prawnych" (Wróblewski 1956, 843). Uszczegółowiając, w duchu teorii derywacyjnej, wskazany generalny cel interpretacji prawnej, stwierdzić można, że „celem wykładni jest odtworzenie norm wysłowionych $\mathrm{w}$ przepisach prawnych wraz z percepcją ich treści" (Zieliński 2017, 251).

Interpretacji tekstu literackiego, rzecz jasna, takich wymagań stawiać nie można, jednak sposób prowadzenia interpretacji tego tekstu w jakimś zakresie zdeterminowany jest przez pewien proces, któremu podlega część przynajmniej kultury - chodzi mianowicie o idiosynkratyzację kultury zachodniej. Pojęcie to przywołuję za Szahajem, który ujmuje idiosynkratyzację kultury zachodniej jako, ,[... [ rozszerzenie zakresu indywidualnych sposobów uczestniczenia w kulturze, tolerowanych przez otoczenie i jednocześnie nieprowadzących [jeszcze] do zerwania komunikacji wewnątrzkulturowej" (Szahaj 2012, 216)9. Jak doprecyzowuje Szahaj, ,kultura zidiosynkratyzowana żywi się wielością interpretacji, wielość interpretacji pogłębia idiosynkratyzację kultury” (Szahaj 1997, 24). Wielość interpretacji, niejako „wymuszana” przez zidiosynkratyzowaną kulturę, posiłkować się musi również kryteriami pozatekstowymi dla zbudowania interpretacji z poziomu significance - $\mathrm{w}$ innym razie zakres możliwych interpretacji jednego tekstu literackiego byłby co najmniej ograniczony.

Patrząc z szerszej perspektywy, opisaną powyżej rozbieżność umieścić można w nieprzekraczalnej moim zdaniem różnicy na poziomie celów przypisywanych prawu oraz tekstom literackim ujmowanych jako wytwory kulturowe. Lapidarnie ująć można ją w ten sposób, że interpretacja tekstu prawnego dąży do zacierania różnic w konstruowanych znaczeniach tego tekstu, podczas gdy interpretacja tekstu literackiego dąży do podkreślania i tworzenia różnych

\footnotetext{
${ }^{9}$ W części II cytowanego opracowania Szahaj wskazuje również na źródła idiosynkratyzacji kultury zachodniej.
} 
znaczeń danego tekstu. Na poziomie znaczeń tekstu prawnego bardzo dobrze widoczne jest to na gruncie orzecznictwa unijnego - jak pisze Marek Zirk-Sadowski: „Jeżeli określone znaczenie tekstu prawnego było już przedmiotem orzecznictwa i ustaliła się linia orzekania, to mówi się, że tekst jest jasny. [...] (Jest to - J. J.) stwierdzenie faktu istnienia zgody między sędziami, co do znaczenia prawa" (Zirk-Sadowski 2016, 160). Tego typu jasność ${ }^{10}$ wydaje się być stanem, do którego zdążają wysiłki nauki prawa (w szczególności w jej części zajmującej się wykładnią). Na gruncie koncepcji derywacyjnej przyjąć można, że należy osiągnąć jednoznaczność znaczeniową, która zrelatywizowana jest na moment, w którym dokonywana jest interpretacja. Niezależnie jednak od tego, czy jednoznaczność ta ma charakter zrelatywizowany, czy też „absolutny", to jednak na gruncie zinterpretowania i rozstrzygnięcia konkretnego przypadku wysiłki interpretatora dążą do unicestwienia mnogości możliwych znaczeń danej regulacji.

Z drugiej zaś strony, „sztuka (którą współtworzą niewątpliwie teksty literackie - J. J.) zaś już od czasów romantyzmu miała wpisany w siebie imperatyw mnożenia różnic, nie zaś ich zacierania" (Szahaj 1997, 25). Wydaje się, że to właśnie do takiego myślenia o sztuce odwołują się dekonstrukcjoniści - zwłaszcza jeżeli chodzi o tworzoną przez nich teorię interpretacji. Negują oni esencjalistyczne pojmowanie tekstu (jego znaczenia), poprzez zastosowanie zabiegu dekonstrukcji, który

[...] ma pokazać raczej niemożność zaistnienia takiej prawdy [takiego znaczenia] (wypracowanej przez hermeneutyczne zespolenia autonomicznego znaczenia tekstu $\mathrm{z}$ elementami 'wnoszonymi' przez interpretatora - J. J.) przez kompromitację wszelkich ustalonych z góry tradycyjnych możliwości uchwytywania metafizycznego porządku świata i języka (Szahaj 2012, 167).

Rozumiejąc prawdę w kontekście interpretacji tekstów (prawnych i literackich) jako wytworzenie w miarę możliwości obiektywnego i jednoznacznego znaczenia tekstu, stwierdzić można, że wysiłki teorii prawa dążą do osiągnięcia tej prawdy, natomiast wysiłki teoretyków interpretacji tekstów literackich mogą dążyć do ukazania, że osiągnięcie takiej prawdy jest po prostu niemożliwe. Warto skonkludować również, że wspomniane obiektywne i jednoznaczne znaczenie w kontekście interpretacji tekstów prawnych osiągnięte może być wyłącznie w odniesieniu do konkretnego i określonego modelu interpretacyjnego - reguły i dyrektywy tego modelu mogą zapewnić obiektywność, lecz, rzecz jasna, wyłącznie na gruncie przyjętego modelu interpretacyjnego.

${ }^{10}$ Jasność ta nie ma jednak nic wspólnego z koncepcją clara w rozumieniu J. Wróblewskiego - ta odnosi się do immanentnej własności danego terminu, jakim jest jego znaczenie, uchwytywane w akcie bezpośredniego rozumienia, a nie do faktycznej zgody co do rozumienia prawa. 


\section{WNIOSKI KOŃCOWE}

Artykuł ten traktować należy jako próbę przygotowania płaszczyzny porozumienia między interpretacją tekstów prawnych a literackich. Choć, jak wskazywałem, już na poziomie celów stawianych interpretacji tych dwóch rodzajów tekstów zachodzi poważna różnica, to jednak nie do zignorowania pozostaje fakt, że zarówno teksty prawne, jak i teksty literackie są wytworami działalności człowieka współkonstytuującymi obszar kultury - z tej też przyczyny ich zestawianie uznaję za uzasadnione. Co więcej, jak starałem się wykazać w artykule, pomimo wspomnianej zasadniczej różnicy, da się również wyróżnić elementy, które zbliżają do siebie interpretację tekstów prawnych oraz tekstów literackich.

\section{BIBLIOGRAFIA}

Choduń, Agnieszka. 2016. „Koncepcja wykładni prawa Macieja Zielińskiego”. Ruch Prawniczy, Ekonomiczny i Socjologiczny 4: 57-67.

Choduń, Agnieszka. Maciej Zieliński. 2009. „Aspekty granic wykładni prawa”. W Księga jubileuszowa Profesora Ryszarda Mastalskiego. Stanowienie i stosowanie prawa podatkowego. Red. Wiesława Miemiec, Eugenia Fojcik-Mastalska. 84-95. Wrocław: Oficyna Wydawnicza Unimex.

Czepita, Stanisław. Sławomira Wronkowska. Maciej Zieliński. 2013. „Założenia szkoły poznańsko-szczecińskiej w teorii prawa". Państwo i Prawo 2: 3-16.

Hirsch, Eric Donald. 1977. „Interpretacja obiektywna”. Tłum. Piotr Graff. Pamiętnik Literacki 3: 289-320.

Ingarden, Roman. 1960. Spór o istnienie świata. Tom 1. Warszawa: Państwowe Wydawnictwo Naukowe.

Jabłoński, Paweł. Przemysław Kaczmarek. 2017. Granice władzy prawniczej w perspektywie polskiej tradycji socjologicznej. Kraków: NOMOS.

Jabłoński, Paweł. Przemysław Kaczmarek. 2020. „O grze interpretatora z tekstem prawnym i czynnikami pozatekstowymi w derywacyjnej koncepcji wykładni prawa". Archiwum Filozofii Prawa i Filozofii Spolecznej 2: 49-68.

Pałecki, Krzysztof. 1988. Prawo. Polityka. Władza. Warszawa: Centralny Ośrodek Metodyczny Studiów Nauk Politycznych.

Radbruch, Gustav. 2009. Filozofia prawa. Tłum. Ewa Nowak. Warszawa: Wydawnictwo Naukowe PWN.

Smolak, Marek. 2003. Uzasadnienie sadowe jako argumentacja z moralności politycznej. O legitymizacji władzy sędziowskiej. Kraków: Zakamycze.

Sontag, Susan. 2012a. „O stylu”. Tłum. Anna Skucińska. W Przeciw interpretacji i inne eseje. Red. Dariusz Żukowski. 27-56. Kraków: Wydawnictwo Karakter.

Sontag, Susan. 2012b. „Przeciw interpretacji”. Tłum. Dariusz Żukowski. W Przeciw interpretacji i inne eseje. Red. Dariusz Żukowski. 10-26. Kraków: Wydawnictwo Karakter.

Szahaj, Andrzej. 1997. „Granice anarchizmu interpretacyjnego”. Teksty Drugie 6: 5-33.

Szahaj, Andrzej. 2012. Ironia i miłość. Neopragmatyzm Richarda Rorty'ego w kontekście sporu o postmodernizm. Toruń: Wydawnictwo Naukowe Uniwersytetu Mikołaja Kopernika.

Szkłowski, Wiktor. 2006. „Sztuka jako chwyt”. Tłum. Ryszard Łużny. W Teorie literatury XX wieku. Antologia. Red. Anna Burzyńska, Michał Paweł Markowski. 95-111. Kraków: Znak. 
Teissier-Ensminger, Anne. 2004. La fortune esthétique du Code civil des Français. Paryż: Éditions La Mémoire du Droit.

Wróblewski, Jerzy. 1956. „Wykładnia prawa a terminologia prawna”. Państwo i Prawo 5-6: 843865.

Zieliński, Maciej. 2006. „Derywacyjna koncepcja wykładni jako koncepcja zintegrowana”. Ruch Prawniczy, Ekonomiczny i Socjologiczny 3: 93-101.

Zieliński, Maciej. 2017. Wykładnia prawa. Zasady, reguły, wskazówki. Warszawa: Wolters Kluwer.

Ziembiński, Zygmunt. 1960. „Przepis prawny i norma prawna”. Ruch Prawniczy, Ekonomiczny i Socjologiczny 1: 105-122.

Ziembiński, Zygmunt. 2004. Logika praktyczna. Warszawa: Wydawnictwo Naukowe PWN.

Zirk-Sadowski, Marek. 2016. „Problemy wyboru pomiędzy konkurującymi modelami wykładni prawa”. Acta Universitatis Wratislaviensis. Przegląd Prawa i Administracji 104: 155-169. 